\title{
Principal Spiritual Leadership in Strengthening Character Education Through the Teachings of Shalawat Wahidiyah at Vocational High School Ihsanniat Jombang Indonesia
}

\author{
Rofiatul Hosna \\ Islamic Studies, Hasyim Asy’ari University, Indonesia \\ rofiatul_hosnah@yahoo.com
}

\author{
Imron Arifin \\ Department of Educational Administration, State \\ University of Malang, Indonesia \\ imron.arifin.fip@um.ac.id
}

\begin{abstract}
The purpose of this research is to know principal leadership in strengthening character education through the teachings of Shalawat Wahidiyah at Vocational High School of Ihsaniyat at Jombang. This study used a qualitative approach with the design of case study. The techniques of data collection in this study are the use of observation, interviews, and documentation. The techniques of data analysis are data collection, data reduction, data presentation, drawing conclusions/ verification. Criterion validity of the data is based on the credibility, transferability, dependability, and confirmability. The results were obtained: spiritual leadership became an inspiration and an example in strengthening character education; leaders use the teachings of Shalawat Wahidiyah as the basis of character education; their characters can be seen from several aspects: attitude, emotions, beliefs, habits and self-conceptions. The spiritual leadership of the principal in character education is done through stages: internalization, personification, socialization, and spiritual values in schools and the community.
\end{abstract}

Keywords: principal spiritual leadership, shalawat wahidiyah, vocational school

\section{INTRODUCTION}

The success of a nation in achieving its goals is not only determined by the abundance of natural resources, but also greatly determined by the quality of its human resources. Some even say that "Great nation can be seen from the quality/character of the nation (human) itself" (Majid \& Andayani, 2011). With regard to human resources, Socrates has said that the most fundamental goal of education is to make a person a good and smart human (Majid \& Andayani, 2011). This means that education does not emphasize the intellectual aspect only, be smart, smart and have high academic achievement, but also be a good person, be good people or good person,that is to be a person having good character and character. In Islamic treasury, Prophet Muhammad brings the main mission of educating human beings to perfect morals and strive for the formation of good character, namely the formation of a good human personality and cautious to Allah (Majid \& Andayani, 2011).

Indeed, in the Messenger of Allah (Muhammad), there are examples of role models for those who depend on Allah and the Hereafter and have a lot of remembrance of Allah (QS Al Ahzab 33:21). However, the development of akhlak pioneered by Rasulullah Saw through uswah hasanah for Muslims gradually eroded the times as the impact of the current globalization. According to Hasan (2004) globalization is a phenomenon of two decades lately, fueled by advances in transportation technology and economic progress or industrialization. It comes across the boundaries of national sovereignty of every country, whether developed or developing. The flow of globalization is coming faster and stronger. The influence of the current globalization can make weak moral discipline.

In general, vocational high school students are at the age of 16-19 years, or adolescence. Personal and social growth at this stage of age, characterized by the need to express themselves, want to be respected, recognized and trusted by the environment, especially by peers. They do not want to be ostracized from the group, because they need friends to develop their personality. Such circumstances that often encourage adolescents to follow and imitate what is done by friends including negative things (Furqona, 2001). In addition, various psychotropic and narcotics are also widely circulated among school children. More terrible, sellers and buyers are also people who are still students (Majid \& Andayani, 2011).

Moral formation through high school vocational is very important and not easy. Especially to students who at the previous educational level lack the guidance and guidance of morals quickly and accurately (Majid \& Andayani, 2011). This means that the formation of character or morals is not enough on the level of the material only but how to religious values internalized in the self, born and bear fruit into a noble character or akhlak al-karimah (Arifin, 2010; Sauqi, 2010).

Today, however, modern life makes religious experience more expensive, this modern-day orientation of human life emphasizing materialphysical things makes the religious aspect tends to be in the periphery. Not only much time and energy is given to wrestle about the purpose and meaning of life. In fact, as Betrand Russel affirms, man can not live with a safe spiritual peace without realizing the meaning and purpose of life itself. (Muhyidin, 2005; Sauqi, 2010).

According to research results Guntur (2016) character education is closely related to the leadership of the principal. Principal strategies in building the character of students are done through exemplary, habituating, integrating learning and extracurricular activities and developing school culture. Other research finds that leadership in different contexts and cultures is influenced by morality values such as honesty, integrity, partisanship of truth, and deep emotional and personal engagement across organizational personnel is seen as a key determinant of successful leadership practices of an organization (Brown \& Posner, 2001; Arifin, 2012). The enthusiasm of authentic offerings 
about the values of integrity and truth that appreciate the variation of context and culture by the overall resources of the organization are facts and must be fought and exposed (Bhindi \& Duignan, 1997; Juharyanto, 2012). Authentication of these values leads to the spirit of organizational spiritual motivation and significantly impacts the empowerment of human resources organizations that strengthen the achievement of organizational goals together and perfect (Covey, 2009).

Furthermore, Covey (2009) states that in essence, leadership stems from the intellect, the heart, the mind, and the souls of lead individuals who spread continuously to other organizations' human resources through meaningful interactions. The significance of the interaction is a "solid driver" for the realization of leadership awareness for the organization's human resources in contributing totally to the achievement of effective leadership goals in any era.

From some research on educational leadership at school, it was found that the "excitement" of achievement was only obtained through strong awareness of leadership into the individual on all educational stakeholders encouraged by the exemplary achievement of the principal (Arifin, 2008) in the form of meaningful interaction through utilization the values of leadership based on adjustment with variations of cultural context consistently (Juharyanto, 2012). Leaders are not only aware that they are together, but furthermore they are dynamic human resources who have noble ideals in the future and need places and opportunities to develop optimally for organizational goals as their learning communities (Sergiovanni, 1987; Fullan \& Fullan, 2007; Arifin, 2008; Juharyanto, 2012). Therefore, effective leadership will only occur if ethics and values of leadership become the main basis of leadership in carrying out its leadership (Brown \& Townsend, 1997).

Spiritual leadership relies heavily on the spiritual values that are followed and socialized. Spiritual leadership becomes meaningful when entering the era of ASEAN Economic Community (AEC) and globalization, because the interaction and synergy of global development has a positive and negative impact on education. The principal has an important role as an educational leader to give clear directions and teachings about a pure bastion of heart based on spiritual values (Arifin, 2010). It is interesting to examine the discussion of leadership in the context of the "trends" of the community, especially in facing the reality of the agreement of ASEAN countries in implementing the AEC at the end of 2015 becomes very important, especially if juxtaposed with statistical data quality Indonesia Human Resources relatively low, and thrust out the substantive helplessness and inadequacy of the AEC that is already in sight. Whatever the condition of the people of Indonesia, the arrival of the AEC can no longer be rejected. Preparing the quality of Indonesian society in accordance with the standards of the AEC is a necessity, and must be realized not only the sphere of government alone, but at the same time society as a whole. Of course, in a short time, only the independence of society that can anticipate quickly and accurately, without depending from other parties.

In East Java there are orders of follower thariqoh Shalawat Wahidiyah that the number is pretty much up to the country and even to foreign countries like Malaysia, Brunei Darussalam, Australia, Suriname, Netherlands, Saudi Arabia, Japan, Hong Kong, and others. The members of Shalawat Wahidiyah not only adults or parents but there are practices of children and adolescents in accordance with the principle broadcasting Shalawat Wahidiyah is "broadcast to anyone indiscriminately to jami'al 'alamin.

Ihsanniat Vocational School is one of the formal institutions under the Ministry of Education and Culture (Kemendikbud) in Jombang region owned by practices of Wahidiyah. This school is one of the institutions under the auspices of Yayasan Pendidikan Ihsanniat, At-Tahdzib Pesantren, Rejoagung Village Ngoro Sub-district, Jombang District, East Java Province, Indonesia, which is one of the institutions that dare to implement and develop the education syllabi of Shalawat Wahidiyah. In this syllabi other than talking about Shalawat Wahidiyah and his teachings are also explained how the application of the material in everyday life as well as some practical activities in the classroom that can nurture the noble character of the students.

Another interesting and important thing to investigate vocational schools with spiritual leadership can run teaching and learning activities that are vocational material but based on the teachings of religion-based characters primarily the teachings of Shalawat Wahidiyah

\section{METHODS}

This study used a qualitative approach, with a single case study design. The instrument of this study is the researchers themselves because in qualitative research there is no other choice than to make human beings as the main research instrument (Arifin, 2000). Data collection techniques in this study used in-depth interviews, participant observation, and documentation study. Data Analysis Technique using funnel system (Bogdan \& Biklen, 1988) by following step Milles and Huberman (1994) that do data reduction; display data; and data verification/conclution drawing. While the technique of examining the validity of the data follow the instructions of Lincoln and Guba (1992) namely credibility; dependability; and confirmability.

\section{RESULT AND DISCUSSION}

The implementation of the headmaster's spiritual leadership in the organization of character education is guided by the School Activity Plan (SAP), which covers the academic field and the field of culture carried out by involving all school residents, parents, and principals as role models and motivators. This finding is in line with the Ministry of National Education (2011) policy, which outlines how to apply leadership in schools. Kemendiknas (2010) describes the development of character education in schools, at least through three integrated processes, namely 
character education through: (1) integrated learning process; (2) integrated school management; and (3) student activities. This means, the character education process requires a pattern of development that is holistic and coordinated in every aspect of school activities.

The principal has a dual role as an educational leader and as a school manager. In his role as an educational leader, the principal provides motivation and inspiration in the values, norms, and culture of schools whose sources of value are elevated from the values of Wahidiyah moral teachings. As school manager, the principal is the person who is given the task and responsibility to manage all matters relating to school management, collect, utilize, and move the entire potential of the school optimally to achieve the goal. The principal in this case acts as an advisor when working with other managers regarding human resource management (HRM). Management of education by creating a conducive learning environment on an ongoing basis is a shared commitment of school education managers. The ability of the school principal in these findings supports the findings of Petterson (Kemendiknas, 2010) on effective leadership in carrying out his duties based on values, ideology, and philosophy (Arifin, 2016).

With regard to the era of ASEAN economic community, almost all students use hand phone (HP) in communicating and interacting. Using HP has both positive and negative impacts. In order to prevent negative usage such as violence and pornography, the headmaster through spiritual leadership stimulates and persuasion to all students to base all actions and behaviors in accordance with Wahidiyah teachings. It is meant to print students mastering science and technology as well as religious values. The principal in his leadership fosters motivation and enthusiasm for the citizens of the school to become religiousintellectual and intellectual religously (Arifin, 2012).

The residents of Vocational High School (VHS) Ihsanniat Rejoagung Ngoro Jombang, the practice of Shalawat Wahidiyah practice is commonly known by the practice with the term Mujahadah seriously fighting and subjugating lust to be directed to the awareness of trasendetal. Fafirruu Ilallah Wa Rasulihi (back in obedience to God and His Messenger, Prophet Muhammad).

Mujahadah ethics includes: Wahidiyah inspiration with closeness and obedience to God and the Apostle; commitment and concentration of presence (hudur) only to God and the Prophet with sincerity, ta'dhim (glorify) and mahabbah (love) as deep and pure-pure; tadhallul is self-esteem; tazallum is sinful and dholimous; iftiqar feels that it needs once; munajat that is always praying, begging for good self, family, people, nation, state, and religion.

Implement aurod or wirid in mujahadah in order to be given God intelligence, security, improvement of science and achievement, finance, fluency of struggle, agriculture, prosperity, happiness, blessing in life and all kinds of affairs. In the activities of worship mujahadah wahidiyah conducted based on the time: yaumiyah (daily) ie students of Vocational
School Ikhsaniyat read prayers and prayers before going to class every day; usbu'iyah (weekly) ie praying and praying once a week, performed after the ceremony held once a week; syahriyah (monthly) ie students of Vocational School Ihsaniyat held a prayer and praying event by inviting the surrounding community and Wahidiyah followers to be active in monthly meetings; rubu'ussanah (three months) of prayer and shalawat activities conducted four times a year or three months, bus execution in the school hall, in the cottage, or in the houses of residents with the approval of the central board of Shalawat Wahidiyah; nishfussanah (six months) that is implemented in the province, if it takes time and place outside the city then the school will dismiss because all the citizens of the school are active in the activity; kubro (the great of activity) as the biggest event for the rahidiyah practice.

The practicer throughout Indonesia even abroad will be present in the framework of prayer together for the blessing and safety of the nation and state. This activity is held twice a year. That is every month Muharram and Rajab to commemorate isra' mi'raj Rasulullah Saw also at the same time commemorate the founder Shalawat Wahidiyah. These activities are similar to Guntur's (2016) findings that character education is conducted in schools through extracurricular activities and the development of school culture. Also through religious education activities (Furqona, 2001; Huda, 2015; Mahjuddin, 2009; Margadinata, 2010).

In addition to the activities mentioned, was also found that mujahadah waqtiyah, activities simultaneously carried out at certain times or when there is an interest, a case mujahadah warning New Year Hijri and Masihiyah, anniversary of independence day, memorial day-to-day National large, night Nishfu Sya'ban, warning revelation of the Qur'an, night Idul Fitri, mujahadah going to tomb in the month of Shawwal, mujahadah proximate to wukuf hujjaj at Arafat, mujahadah toward an important event or special mujahadah conducted specifically in connection with the special things like mujahadah special improvement, toward one events, security, intelligence, development, istikhoroh, agriculture, and type a hajat. Spiritual approach to character education in vocational high schools al-Ihsaniyat had similarities with the results of thunder (2016), the study also Suyono (1998) and Kotten (2012) that the implementation of instructional supervision spiritual insight done through professional help with sticking to religious values. Research Saleh also found a spiritual approach carried out by private teachers and students manage intelligence and the nature or character of goodness (Kotten, 2012). According Sukidi (2004) that the leadership of the principal is effective by managing his spiritual intelligence based on religious sources of values.

The steps of character building through the internalization of the spiritual values of Shalawat Wahidiyah applied principals to teaching and learning activities in Ihsanniat vocational schools through routine mujahadah activities and reading nida' for Rasulallah. The material of wahidiyah is integrated 
with other subject matter, such as Sholawat and its legal basis, the ulama's opinion about sholawat, Shalawat Wahidiyah and its teachings, mujahadah and $a d a b-a d a b$ and its various kinds, the history of wahidiyah, and wahidiyah organization.

Internalization of value is also implemented through wahidiyah upgrading that is after the implementation of National Examination. Target of this upgrading participants is all students of class 3 . This activity is intended that after they graduate school they have provisions on the matter of wahidiyah which will be back to their respective areas of the material will be useful in solving the problematic struggle wahidiyah in its area.

The conscious awakening movement box, is a "tarbiyyah package" for easy charity and infak treasure/money according to ability, awareness, and sincerity respectively. Habit and exemplary become an important agenda in planting spiritual values shalawat wahidiyah. By doing good habits it is inherent in him and spontaneity becomes character. For example, honesty canteen, where students serve themselves when buying food including payment problems. The study of al-Hikam by Sheikh Ibnu Athaillah which contains the cleansing of the heart and the sanctity of the soul which is also related with Wahidiyah's book is favored by the students. In addition, this study was also attended by surrounding communities. Such as Orange Fragrance, Kasreman, Junggo, Josari, Cermenan, and Kedawung.

Various measures of value internalization in the vocational school of Ihsaniat have similarities with the findings of research Effendi (2009) that the internationalization of values and the formation of personal character of students who are humanist, moral, and religious is done through activities that give rise to the value of "bonum hominis" (The value of humanity) that is the value of human virtues and virtues with the atmosphere of true brotherhood, kinship, joy, and balance of intellectual, emotional, and spiritual intelligence. Internalization of this value is intended to educate and improve the heart (Wening, 2012; Muhyidin, 2005; Nata, 2013; Samani \& Hariyanto, 2013; Muin, 2011).

In general, the character of students of Vocational School Al-Ihsanniat good, does not happen pupil vandalism and student mischief. Character indicators include: attitude, shown by speaking politely, respecting and tawadlu' to the teachers, obedient to the teacher's instructions and so forth. Cultivating smiles, greetings, greetings and salim (great each other with shake hands) when meeting teachers and so forth; the students' emotions are well controlled. Even their emotional-sociological soul is also good. It is seen when they get a problem or a test or something that is surprising, they are able to take leave of God; Trust in God increases with the commitment of religion. Habit of congregation together, mujahadah together, pray together, group work, greet each other with friends and so on; and self conception that they are able to conceptualize or motivate themselves well. In addition, students of
Vocational School Ihsanniat also never recorded a serious violation to deal with the authorities.

The spiritual leadership of the principal is done through the stages. First, the internalization of Wahidiyah values. Secondly, the values are manifested in personality or personification process, Third, the headmaster socializes by forming Wahidiyah groups among teachers and students. Last headmaster cultivates Wahidiyah into a part of teaching and learning activities daily. The findings of this study are in line with the findings of Effendi (2009) and Kotten (2012) that the unity of values, unity of mind, unity of actioon, and unity of comand conducted by principals and teachers in the plan and implementation of student activities based on moral and spiritual values can produce character traits effectively.

\section{CONCLUSION}

Based on the above discussion, the researcher can draw the following conclusion: (1) the spiritual leadership of the school principal is run through a dual role as educational leader and school manager through exemplary personality, religious commitment, and school work plan; (2) character education is done through a spiritual approach based on Shalawat Wahidiyah teachings known as mujahadah teachings, both mujahadah that are general or special; (3) interalisasi spiritual values in Shalawat Wahidiyah for the formation of noble characters of students of Vocational School Ihsanniat, among others through: Through routine mujahadah, reading nida' either orally or in the heart, the material of wahidiyah and integration with other materials, training or upgrading Wahidiyah, Aware Awareness Movement Box (AAMB), habit and exemplary, and reciting the book of al-Hikam and deepening Wahidiyah; and (4) the spiritual leadership of the principal in character education is done through stages: internalization, personification, socialization, and spiritual values in schools and the community.

\section{REFERENCES}

[1] Arifin, I. 2008. Kepemimpinan Kepala Sekolah dalam Mengelola Sekolah Berprestasi: Studi Multikasus pada MIN Malang I, MI Mamba'ul Ulum, dan SDN Ngaglik I Batu Malang. Yogyakarta: Aditya Media.

[2] Arifin, I. 2012. Kepemimpinan Kepala PAUD dalam Mengimplementasikan Pembelajaran Sentra: Studi Kasus PAUD Unggulan Nasional Anak Saleh Malang. Yogyakarta: Aditya Media.

[3] Arifin. I. 2010. Kepemimpinan dan Pendidikan Berbasis Karaktek di Indonesia. Oration on Wisuda Sarjana \& Pascasarjana IKAHA Jombang, 31 October.

[4] Bhindi \& Duignan. 1997. Leadership for a New Century, Authenticity, Intentionality, Spirituality and Sensibility. Educational Management \& Administration, 25(2), 117.

[5] Bogdan, R., \& Biklen, S. K. 1998. Qualitative Research for Education: An Introduction to Theory and Methods. New York: Allyn and Bacon.

[6] Brown, J. \& Townsend, R. 1997. Developing an Ethical Framework. Thrust for Educational Leadership, 27(3), 12-14.

[7] Brown, L. M., \& Posner, B. Z. 2001. Exploring the 
Relationship between Learning and Leadership. Leadership \& Organization Development Journal, 22(6), 274-280.

[8] Covey, S. 2009. Leadership Great Leaders, Great Teams, Great Results. New York: Batam.

[9] DPP PSW. 1997. Pedoman Pokok-Pokok Sholawat Wahidiyah \& Ajaran Wahidiyah. Jombang: DPP PSW.

[10] DPP PSW. 2009. Tuntunan Mujahadah dan Acaraacara Wahidiyah. Jombang: DPP PSW.

[11] Effendi, Y. R. 2009. Implementasi Pendidikan Moral: Studi Multisitus di SMPK St. Maria 2 dan SMPK Sang Timur Malang. Thesis. Malang: State University of Malang.

[12] Fullan, M., \& Fullan, M. 2007. The New Meaning of Educational Change. New York: Teachers College Press.

[13] Furqona, R. 2001. Pendidikan Agama dan Akhlak Bagi Anak dan Remaja. Ciputat: Logos Wacana Ilmu.

[14] Guntur, E. 2016. Peran Kepemimpinan Kepala Sekolah dan Guru dalam Membangun Karakter Siswa. Dissertation. Malang: State University of Malang.

[15] Hasan, M. 2004. Islam \& Masalah Sumber Daya Manusia, Jakarta: Lantabora Press.

[16] Huda, S. 2015. Tasawuf Kultural: Fenomena Sholawat Wahidiyah. Surabaya: Imtiyaz.

[17] Juharyanto. 2012. Implementasi Kompetensi Kepala Sekolah sebagai Agen Perubahan pada Sekolah Berprestasi: Studi Multikasus pada Tiga Sd/Mi Berprestasi di Kabupaten Bondowoso, Kabupaten Jember, dan Kabupaten Situbondo. Dissertation. Malang: State University of Malang.

[18] Kotten, N. B. 2012. Supervisi Pengajaran Berwawasan Spiritual di Sekolah Dasar: Studi Multisitus SDK Onekore 2 St. Ursula, SDK St Antonius 2, dan SDN Ende I di Kabupaten Ende. Dissertation. Malang: State University of Malang.

[19] Lickona, T. 2013. Pendidikan Karakter (Educating For Character). Bandung: Nusa Media.

[20] Mahjuddin. 2009. Akhlak Tasawuf 1: Mukjizat Nabi Karomah Wali dan Ma'rifah Sufi. Jakarta: Kalam Mulia.

[21] Majid, A., \& Andayani, D. 2011. Pendidikan Karakter Perspektif Islam. Bandung: Remaja Rosdakarya.

[22] Margadinata, W. 2010. Spiritualias Shalawat. Malang: UIN-Maliki Press.

[23] Miles, M. B., \& Huberman, A. M. 1994. Qualitative Data Analysis: A Sourcebook. Beverly Hills: Sage Publications.

[24] Muhyiddin, A. 2005. Kecerdasan Jiwa: Rahasia Memahami dan Mengobati Sakit dalam Hati. Yogyakarta: Arruz Media.

[25] Muin, Fatkhul. 2011. Pendidikan Karakter Kontruksi Teoretik dan Praktik. Jogjakarta: Arruz Media.

[26] Nata, Abudin. 2013. Akhlak Tasawuf dan Karakter Mulia. Jakarta: Raja Grafindo Persada.

[27] Prayitno \& Belferik, M. 2011. Pendidikan Karakter dalam Pembangunan Bangsa. Jakarta: Kompas Gramedia.

[28] Qusyairi, A., Qasim, A., and Hawazin, K. 2007. Risalah Qusyairi. Jakarta: Pustaka Amani.

[29] Samani, M., \& Hariyanto. 2013. Konsep dan Model Pendidikan Karakter. Bandung: Remaja Rosdakarya.

[30] Sauqi, A. 2010. Meraih Kedamaian Hidup: Kisah spiritualitas Orang Modern. Yogyakarta: Teras.

[31] Sergiovanni, T. J. 1987. Educational Governance and Administration. Englewood Cliffs, NJ: Prentice-Hall, Inc.

[32] Sergiovanni, T.J. 2007. The Principalship: A Reflective Practice Perspective. Boston: Allyn and Bacon, Inc.
[33] Sukidi. 2004. Rahasia Sukses Hidup BahagiaKecerdasan Spiritual: Mengapa SQ Lebih Penting Daripada IQ dan EQ. Jakarta: Gramedia.

[34] Suyono. 1998. Profil Kebutuhan Profesional Guru Sekolah Dasar. Jurnal Penelitian Pendidikan Dasar, 2(3), 77-93.

[35] Wening, S. 2012. Pembentukan Karakter Bangsa melalui Pendidikan Nilai. Jurnal Pendidikan Karakter, 64(3), 231-241. 